\title{
Embedding sea surface temperature anomalies into the stock recruitment relationship of red mullet (Mullus barbatus L. 1758) in the Strait of Sicily*
}

\author{
D. LEVI, M.G. ANDREOLI, A. BONANNO, F. FIORENTINO, G. GAROFALO, \\ S. MAZZOLA, G. NORRITO, B. PATTI, G. PERNICE, S. RAGONESE, \\ G.B. GIUSTO and P. RIZZO \\ Istituto di ricerche sulle Risorse Marine a l'Ambiente (IRMA-CNR), Via Luigi Vaccara 61, 91026 Mazara del Vallo (TP), \\ Italy. E-mail: levi@irma.pa.cnr.it
}

\begin{abstract}
SUMMARY: In the Strait of Sicily, red mullet (Mullus barbatus L. 1758) is one of the most important resources for the bottom trawlers exploiting the shelf fishing grounds. At present, the younger age groups (groups 0-1) represent most of the catches. In order to give more effective advice for fisheries management in the area, this paper is aimed at further investigating the stock-recruitment relationship for red mullet by including environmental information. Indices of the mean abundance of red mullet older than 1 year (spawners) and younger (recruits) were obtained from autumn trawl survey samples by analyzing the length-frequency distributions. Sea surface temperature (SST), expressed as the average monthly anomalies over the period from May to September (referring to 1961-90 climatology), was considered as a proxy for oceanographic processes affecting recruitment. An exploratory analysis was performed using three stock-recruitment relationships (Cushing, Ricker and Beverton-Holt), with and without the effect of SST. The best fit $\left(\mathrm{R}^{2}=0.80\right)$ was obtained with a Ricker modified curve $(\ln R=\ln (70.17113)+\ln S-0.063812 S+0.060544(S \cdot E))$, including SST anomalies in July and August as a masking factor. Results showed that, for a given spawning stock level, higher recruitment levels corresponded to warmer than average SST in early life stages.
\end{abstract}

Key words: red mullet, Mullus barbatus, stock-recruitment relationships, sea surface temperature, Strait of Sicily, Mediterranean.

\section{INTRODUCTION}

It is widely recognized that Mediterranean demersal fisheries exploiting several species use various types of gear, but mainly prefer small mesh size trawling (Caddy, 1990; Farrugio and Papaconstantinou, 1998). The majority of the catch includes fish in the first two years of life, with high exploitation rates even on the 0 group (Caddy, 1998).

Since many Mediterranean demersal species of fish and cephalopods are recruited to fishery as 0

\footnotetext{
*Received December 6, 2000. Accepted March 5, 2002.
}

group, understanding the relationships between recruitment strength, spawning stock size and environmental factors appears crucial in order to provide short-term forecasts so that managers can adjust fishing regulations in response to changes in stock size.

It is well known that spawner stock and recruitment relationships (SRR) are one of the most complex issues in the dynamics of exploited resources. In fact, numerous factors may confound these relationships because of the nature of the phenomena and due to bias in data collection (Sissenwine and Shepherd, 1987; Hilborn and Walters, 1992). 
The role of environmental variability in recruitment dynamics of exploited populations has long been recognized and many investigations on this issue can be found in the literature, e.g. Cushing (1982), Glantz (1992), Laevastu (1993), Chambers and Trippel (1997). However, the association between environmental factors and recruitment variability has often been questioned: because of the large number of environmental variables that may be tested for correlation with recruitment, the risk of a significant spurious correlation is high (Botsford, 1987; Walters and Collie, 1988; Hilborn and Walters, 1992).

The aim of this study was to study a specific case of SRR in the Mediterranean, incorporating information on environmental variables affecting recruitment in the model, as suggested by Iles and Beverton (1998). This procedure should enable a simultaneous analysis of the effect of spawners and environmental factors on recruitment, reducing the unexplained variability and improving our understanding of recruitment dynamics.

In this context, the Strait of Sicily represents an excellent test site for studying coupling phenomena between the main oceanographic processes and biological resources because of its limited geographic scale.

Because of its widely-recognized importance and the relative ease with which data can be obtained, sea surface temperature (SST) was considered as an environmental factor potentially capable of affecting inter-annual fluctuations in fish abundance (Templeman and Fleming, 1953; Sissenwine, 1984; Garrod and Shumacher, 1994; Southward and Boalch, 1994). The effect of SST on recruitment is wellestablished for some temperate fish stocks (e.g. Northeast Arctic Cod), but the processes involved are complex (Brander, 1997).

SST could directly affect the early stages of life cycles in fish populations (Brett, 1970; Boeuf, 1988; Wood and McDonald, 1997), but variations in this parameter may also reflect changes in oceanographic processes, e.g. current transport and turbulent mixing, affecting food and larval retention processes. More and more papers suggest that the latter are important in regulating the strength of recruitment (Nelson et al., 1977; Parrish et al., 1981; Lasker, 1981; Bailey, 1981; Bakun, 1985; Corten, 1986; Buckley and Lough, 1987; Peterman and Bradford, 1987; Kennet et al., 1989; Pihl, 1990; Van der Veer et al., 1998; Daskalov, 1999; Sanchez and Gil, 2000).
The biological data presented in this study concern red mullet, Mullus barbatus (L., 1758), one of the most important resources for shelf demersal fishery (down to 200m) in the Mediterranean (Levi et al., 1993; Fiorentini et al., 1997). The investigation was restricted to the red mullet inhabiting the Sicilian side of the Strait, because the biological features of those living on the Tunisian shelf suggest that they belong to another population (Levi et al.,1992; 1994).

The biological characteristics (sexual maturity at 1 year old) and exploitation features (similar vulnerability to trawling from recruitment onward) make red mullet an interesting case for studying the renewal capability of resources in the Mediterranean.

The time series of abundance indices for spawners and recruits used in this paper were obtained as part of programs for evaluating demersal resources in the Italian seas from 1985 onwards (Relini, 1998).

\section{ENVIRONMENTAL AND BIOLOGICAL BACKGROUND}

The Strait of Sicily connects the two main, western and eastern basins of the Mediterranean. At its narrowest section, between Cape Bon (Tunisia) and Mazara del Vallo (Sicily), it is about $130 \mathrm{~km}$ wide (Fig. 1).

Like the Strait of Gibraltar, it is characterized by a two-layer flux model. The upper layer, called "Modified Atlantic Water" (MAW), is identified by water with a relatively low salinity flowing from the western to the eastern basin. The lower layer, called "Levantine Intermediate Water" (LIW), is identified by water with a relatively high salinity flowing in the opposite direction, like an undercurrent (Bethoux, 1980; Manzella et al., 1988; Onken and Sellshopp, 1998).

The complex bathymetry influences the features of the currents in the region. A crest in the middle of the strait divides the flow into two parts: one along the Sicilian shelf, which is narrow and deep, the other off the Tunisian coast, which is wide and shallower. Astraldi et al. (1996) showed that these two parts have two different flows, both for MAW and for LIW. Measurements have shown that the mesoscale signal prevails in the upper layer, with the presence of eddies and meanders.

According to Robinson et al. (1991) the MAW motion, called the "Atlantic-Ionian Stream" (AIS), 


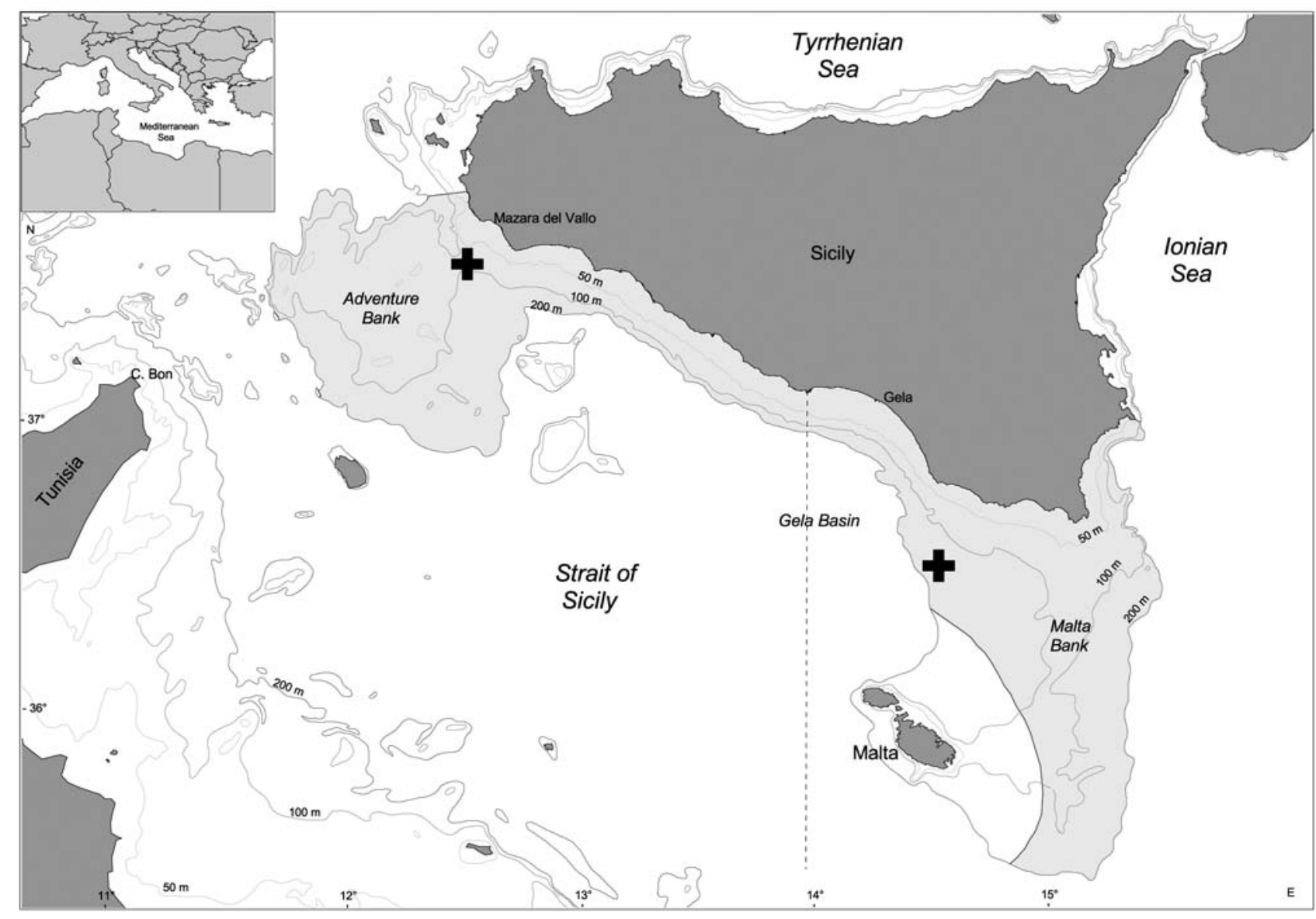

FIG. 1. - The study area with the main bathymetry and the line separating the two sectors. Black crosses represent the position of oceanographic stations.

has quite a steady mean path. It enters the strait from the western boundary along the Adventure Bank (south-western shelf of Sicily), coming close to the Sicilian shore in the middle of the south coast of Sicily (the deep Gela basin) and separates again when it encounters the Malta Bank (south-eastern shelf of Sicily).

The AIS encircles two large cyclonic meanders, identifying two sectors, one around the Adventure Bank on the western side, the other around the Malta Bank to the east. This is illustrated in Figure 2, taken from Mazzola et al. (2000).

A preliminary analysis of the SST at two sites roughly representative of the two sectors was carried out on the basis of 1961-90 climatology data. In particular, the mean annual SST estimated for the western and eastern sectors amounted to $19.3^{\circ} \mathrm{C}( \pm$ $\left.4.2^{\circ} \mathrm{C}\right)$ and $19.9^{\circ} \mathrm{C}\left( \pm 4.1^{\circ} \mathrm{C}\right)$, respectively.

This kind of water circulation favors permanent upwelling to the left of the AIS, which is reinforced by westerly winds (Piccioni et al., 1988; Mazzola et al., 1998).
The offshore transport associated with this upwelling may affect the survival/mortality rates in the early life stages of red mullet, influencing the strength of recruitment.

Since eggs, larvae and post-larvae up to 30-35 $\mathrm{mm}$ of $M$. barbatus are pelagic and live in the surface waters (Lo Bianco, 1908-1909; Montalenti, 1933), the circulation of MAW, with its meanders and upwellings, is assumed to affect red mullet recruitment.

\section{MATERIAL AND METHODS}

\section{SST data}

Monthly $1^{\circ} \mathrm{x} 1^{\circ}$ (spatial resolution) global SST analyses, available from November 1981 to the present day, were obtained from a collection of SST analyses prepared at the National Center for Environmental Prediction (formerly NMC) by D. Reynolds, D. Stokes, and T. Smith. These analyses 


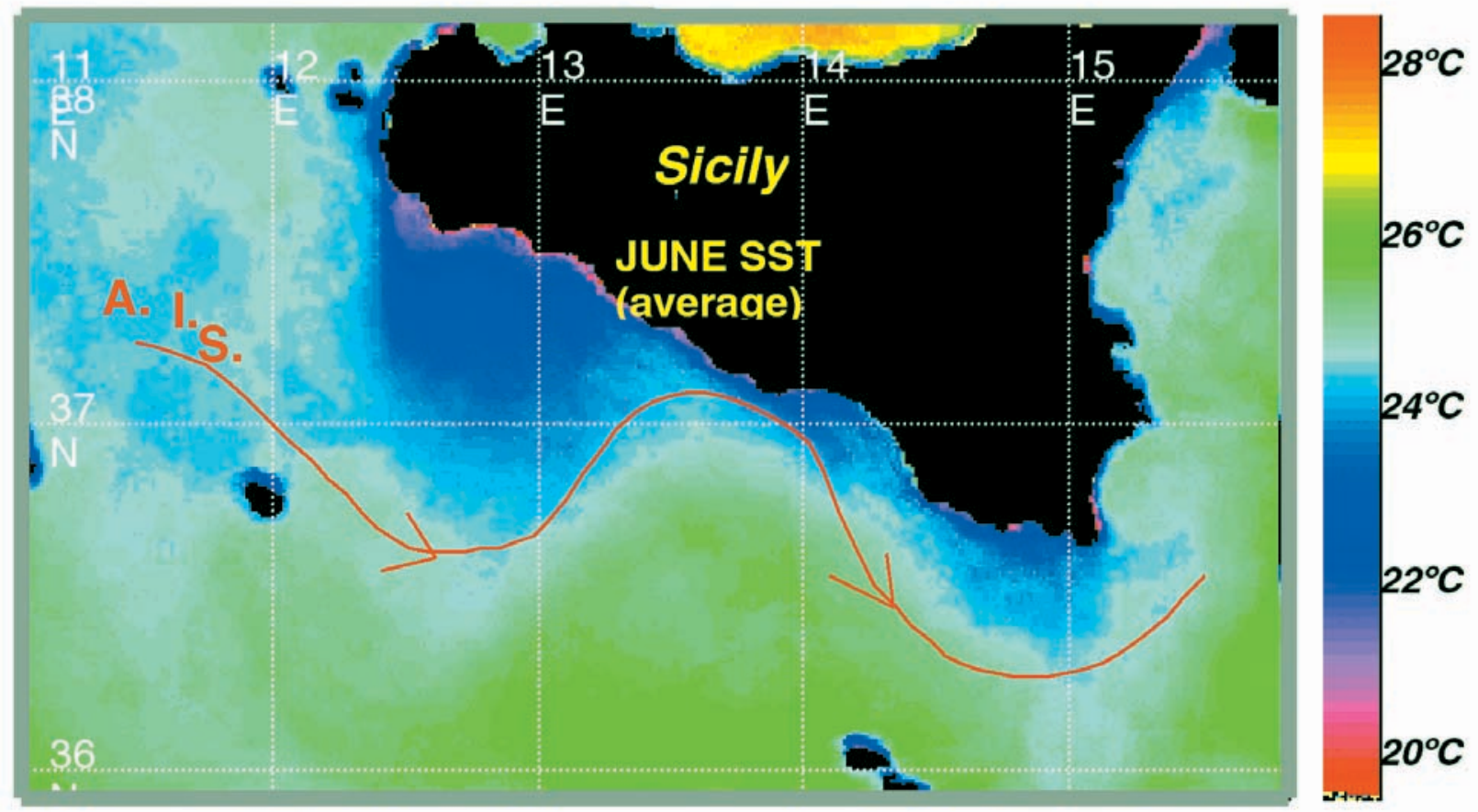

FIG. 2. - Sea Surface Temperature map from NOAA-14 satellite in June 1998. It is a monthly-averaged situation and must be interpreted in terms of the steadiness of certain mesoscale features. The presence of the large blue regions (cool surface water) off Mazara del Vallo (southwestern region of Sicily) and off Capo Passero (southernmost tip of the island) indicate fairly permanent upwelling areas that fit well with descriptions of the general circulation within the Strait. The red line indicates an "averaged" path of the Atlantic-Ionian Stream (AIS) (from Mazzola et al.,2000).

were determined by blending marine surface observations and satellite AVHRR data using an optimum interpolation (OI) method. A description of the OI analysis can be found in Reynolds and Smith (1994). SST data were provided by the Data Support Section of the University Corporation for Atmospheric Research (UCAR), Boulder, Colorado, USA, from their web site at http://dss.ucar.edu/.

From the whole data set, we extracted two SST time series relating to the sites off the southern coast of Sicily shown in Figure 1 (geographical coordinates: $37^{\circ} 30^{\prime} \mathrm{N}-12^{\circ} 30^{\prime} \mathrm{E}$ and $36^{\circ} 30^{\prime} \mathrm{N}-14^{\circ} 30^{\prime} \mathrm{E}$ ), located roughly in the middle of the western and eastern sectors of the study area, where red mullet recruitment is seen to occur.

The Smith and Reynolds (1998) adjusted OI monthly climatology data (base period 1961-1990) for the two above-mentioned locations were used to generate both average monthly SST and monthly anomalies. We restricted our analysis to monthly SST anomalies from May to September because peak spawning for red mullet occurs in May (Levi, 1991) and our aim was to test the influence of the environmental factor (SST anomalies) on the early life stages of the species, before its subsequent recruitment to the fishery.

\section{Stock-Recruitment data}

Samples of red mullet were collected as part of the Italian Programs for evaluating demersal resources in the Strait of Sicily (Levi et al., 1998). Bottom trawl surveys were carried out on an area of about 50,000 $\mathrm{km}^{2}$, between 10 and $800 \mathrm{~m}$ in depth, using a random stratified design. The number of hauls per stratum was proportional to the area of each stratum. The period under study was 1985-98, during which, among others, 6 spring and 9 autumn surveys were carried out.

On the basis of information on spawning and recruitment periods in the area (Levi, 1991), the fish were divided into two groups, i.e. the young of the year forming the 0 group (born in spring and recruited in summer) and the adults (fish older than 1 year), which spawned in spring.

It was assumed that the recruits found on the bottom along southern Sicilian coasts during the autumn of a given year derive from the adults that spawned during the spring of the same year. Since the spring has not been sampled regularly, the spawner indices used in the calculation were also derived from autumn surveys, after verifying that the abundance of spawners after 6 months was proportional to their abundance at spawning time. 
Given the two different meanders around the Adventure and Malta banks, characterized by different average SST, the length-frequency distributions (LFD) were analyzed separately for the western and eastern hauls, dividing the Strait of Sicily as shown in Figure 1.

The identification and strength of age groups in the length-frequency distributions were obtained in 3 steps.

First the overall LFD for each survey was analyzed in order to split the first component and identify the mean length (ML) and standard deviation (SD) of recruits for the year. The LFD components were separated using the NormSep maximum likelihood procedure, as implemented in the FiSAT package (Gayanilo et al., 1996). The preliminary seed values required were obtained by applying the Bhattacharya procedure, again in FiSAT. Then the number of recruits for the year per $\mathrm{km}^{2}(\mathrm{R})$ was calculated for each haul as individuals having a total length from the smallest up to ML + 1SD. Finally, the corresponding biomass of adults per $\mathrm{km}^{2}(\mathrm{~S})$ was simply computed by summing the individual weights of adults.

The simple mean indices of recruits and spawners per $\mathrm{km}^{2}$ for each survey were used directly for modeling purposes.

In order to show the highest-density areas of both recruits and spawners, data were pooled over the years and relative densities were calculated as ratios with respect to the maximum for each year and sector.

All maps were produced with the ArcView-GIS software by ESRI.

\section{Analytical techniques}

Three different classes of stock-recruitment relationship were tested, namely the two-parameter models of Cushing, Ricker and Beverton-Holt, aiming for the best fit of the available data, both with and without incorporating the SST information in the equations. The models reflect the stock-recruitment relationships reported in Iles and Beverton (1998) and are all listed in Table 1. The classification of the environmental influences, given in the table, is based on the work by Neill et al. (1994), who state that environmental factors affecting recruitment can be divided into five kinds: controlling, limiting, lethal, masking and directive. The effects of these factors are broadly discussed by Iles and Beverton (1998). The root conceptual framework can be found in Fry (1947).

In the present study, only three kinds of effect were considered, i.e. controlling, limiting and masking. The first is caused by all factors that alter the rate of change in the numbers of young fish in time; the second by factors that vary the carrying capacity of the habitat for recruits; the third is due to factors that modify the rate of recruitment for any given spawner stock size.

TABLE 1. - Type of S-R models with and without environmental factors affecting recruitment according to Iles and Beverton (1998). Adjusted determination coefficients $\left(\mathrm{R}^{2}\right)$ and estimated equations obtained for different models both including and excluding SST effects (average value of SST anomalies over July and August). Equation (6) shows the best fit to the data, accounting for about $80 \%$ of the total variance. For the purposes of comparison, the models listed in this table have all been fitted in the ln domain by non-linear regression. $\mathrm{R}^{2}$ values of models having at least one parameter not significantly different from zero are in italics.

\begin{tabular}{|c|c|c|c|c|c|c|}
\hline Type of SRR & Equation & $\begin{array}{r}\mathrm{I} \\
\text { env }\end{array}$ & $\begin{array}{l}\text { lusion } \\
\text { the } \\
\text { nmental } \\
\text { ctor }\end{array}$ & $\begin{array}{l}\text { Implicit } \\
\text { role of the } \\
\text { environmental } \\
\text { factor }\end{array}$ & Estimated equation & $\mathrm{R}^{2}$ \\
\hline Cushing & $R=\alpha S^{\gamma}$ & (1) & no & - & $\ln R=\ln (68.28998)+0.875666 \ln S$ & 0.57 \\
\hline Cushing modified & $R=\alpha S^{\gamma} e^{c E}$ & (2) & yes & Controlling effects & $\ln R=\ln (61.50826)+0.776993 \ln S+0.607726 E$ & 0.70 \\
\hline Cushing modified & $R=\alpha S^{\gamma+c E}$ & (3) & yes & Masking effects & $\ln R=\ln (79.55701)+0.633832 \ln S+0.310737 E \cdot \ln S$ & 0.74 \\
\hline Ricker & $R=\alpha S e^{-\beta S}$ & (4) & no & - & $\ln R=\ln (67.68564)+\ln S-0.02645^{(*)} S$ & 0.60 \\
\hline Ricker modified & $R=\alpha S e^{-\beta S} e^{c E}$ & (5) & yes & Controlling effects & $\ln R=\ln (54.07882)+\ln S-0.035348^{(* *)} S+0.618332 E$ & 0.74 \\
\hline Ricker modified & $R=\alpha S e^{-\beta S(1+c E)}$ & (6) & yes & Masking effects & $\ln R=\ln (70.17113)+\ln S-0.063812 S+0.060544(S \cdot E)$ & 0.80 \\
\hline Beverton-Holt & $R=S /(b+a S)$ & (7) & no & - & $\ln R=\ln \left(S /\left[0.015002+0.000434^{(* * *)} S\right]\right)$ & 0.59 \\
\hline B-H modified & $R=S e^{c E} /[b+a S]$ & $(8)$ & yes & Controlling effects & $\ln R=\ln \left(S /\left[0.018309+0.000831^{(*)} S\right]\right)+0.612632 E$ & 0.73 \\
\hline B-H modified & $\left.R=S / b+a e^{c E} S\right]$ & (9) & yes & Limiting effects & $\ln R=\ln \left(S /\left[0.01283+0.001445 e^{-1.76158(* *)} E S\right]\right)$ & 0.74 \\
\hline B-H modified & $\left.R=S \Lambda b e^{c E}+a S\right]$ & $(10)$ & yes & Masking effects & $\ln R=\ln \left(S /\left[0.02078 e^{-0.63956^{(* *)} E}+0.000384^{(* * *)} S\right]\right)$ & 0.70 \\
\hline
\end{tabular}

R: recruits, S: spawners, E: SST

${ }^{(*)}$ parameter not significantly different from zero $(0.1<p<0.3)$.

${ }^{(* *)}$ parameter not significantly different from zero $(0.05<p<0.1)$.

${ }^{(* * *)}$ parameter not significantly different from zero $(0.3<p<0.4)$. 
For the purposes of comparison, the models considered have all been fitted in the ln domain by nonlinear regression.

As for the models incorporating the environmental variable, various combinations of the available monthly SST anomalies were tested to find the best data fit (in terms of higher proportions of variance accounted for), starting from the information for single months and computing all possible average values for 2, 3, 4 and 5 consecutive months, i.e. the average SST anomaly was calculated for: May-June
(MJ), June-July (JJ), July-August (JA), August-September (AS), May-July (MJJ), June-August (JJA), July-September (JAS), May-August (MJJA), JuneSeptember (JJAS), and May-September (MJJAS). The selected variable was consequently included in all models incorporating an environmental effect. After fitting the full models and estimating the parameters, the statistical hypothesis that all these parameters differed significantly from zero was tested.

All statistical analyses were carried out using the STATISTICA for Windows software package.
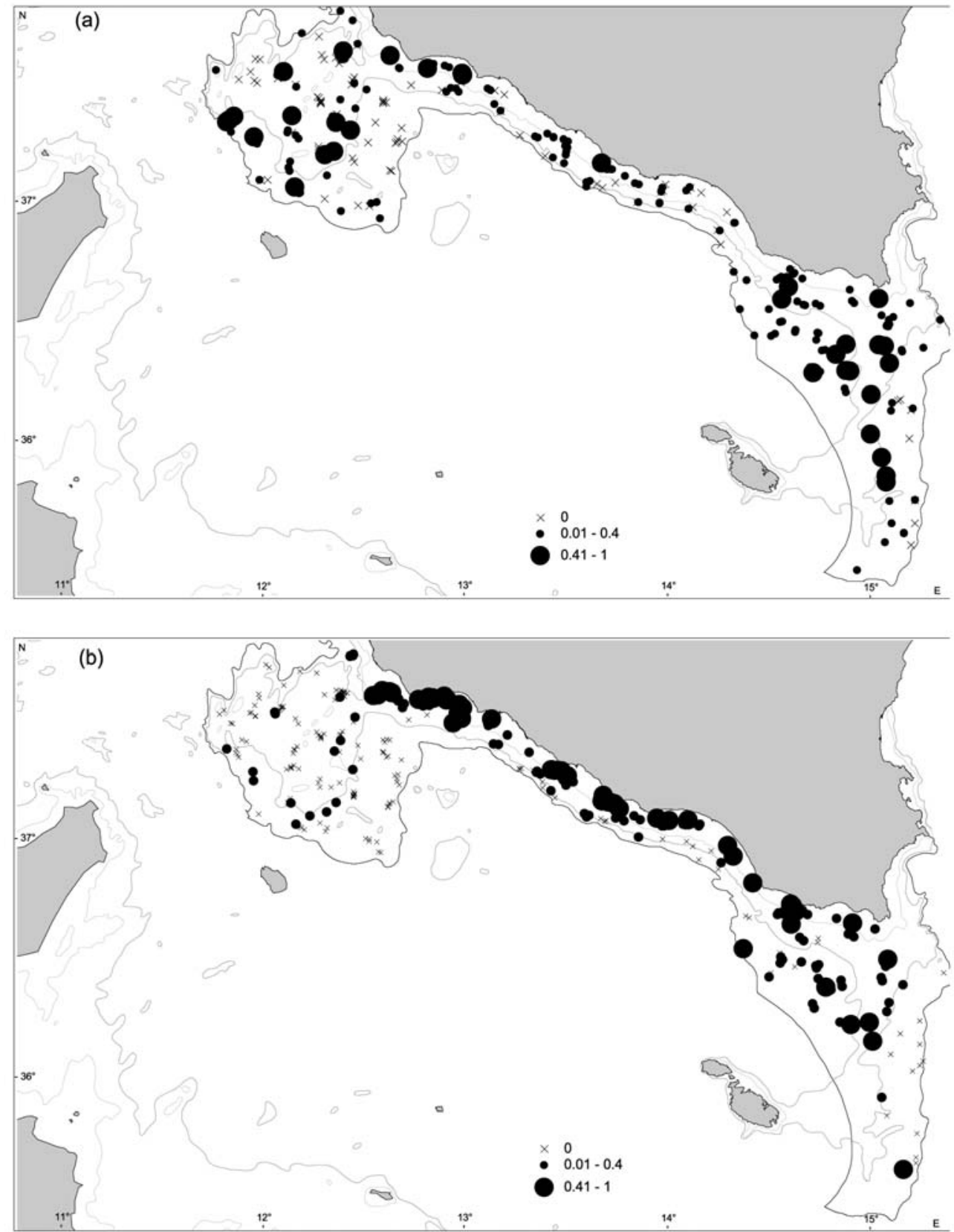

FIG. 3. - Maps of the relative densities of spawners from spring surveys (a) and recruits from autumn surveys (b). In order to show the highest-density areas of both recruits and spawners, data were pooled over the years and relative densities were calculated as ratios with respect to the maximum for each year and sector. 


\section{RESULTS}

The analysis of SST data revealed different temperature patterns for the two sectors of the study area, the SST in the west being consistently lower than in the east. The mean monthly difference was 0.557 , a value which departs significantly from 0 , as demonstrated by applying Student's paired t-test $(\mathrm{t}=$ -15.139 , df $=11, \mathrm{p}>0.005$ ).

Further support for the W-E differentiation of the study area emerged from the synthetic representation of the main nursery and spawning areas, given in Figure 3. The maps show the relative densities of both spring spawners and autumn recruits, and reveal two distinct spawning areas roughly corresponding to Adventure Bank (western sector) and Malta Bank (eastern sector). Spring spawners were more abundant at deeper levels (down to $200 \mathrm{~m}$ ), though in the western sector they even occurred within $50 \mathrm{~m}$ depth (Fig. 3a). Conversely, recruits from autumn surveys were more abundant on very shallow bottoms, but they may be found even to around $100 \mathrm{~m}$ in depth in the eastern sector (Fig. 3b).

The abundance of adults in autumn correlated significantly with the one found in spring $(r=0.56$;

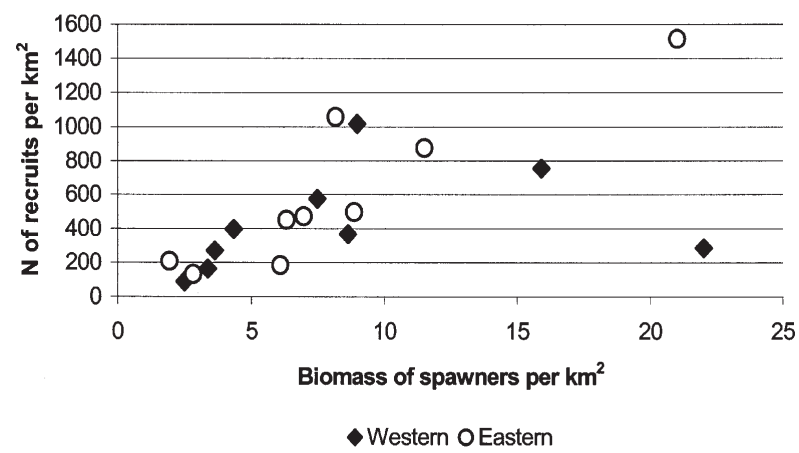

FIG. 4. - Stock-recruitment scatter plot.
TABLE 2. - Parameters and standard errors of the estimated Ricker model (Eq. 6 in Table 1) incorporating the environmental factor as a masking effect.

Model: $\ln (\mathrm{R})=\ln (\alpha)+\ln (\mathrm{S})-\beta * \mathrm{~S}+\mathrm{c} * \mathrm{~S} * \mathrm{SST}$ anom

Dep. var: $\operatorname{Ln}(\mathrm{R})$ Loss: (Obs-Pred $)^{2}$

Final loss: $1.807 \mathrm{R}=0.89$ Variance explained: $80 \%$

$$
\alpha \quad \beta \quad \mathrm{c}
$$

\begin{tabular}{lccc}
\hline Estimate & 70.17113 & 0.063812 & 0.060544 \\
Std.Err. & 12.99323 & 0.020141 & 0.017591 \\
t(12) & 5.400593 & 3.168249 & 3.44172 \\
p-level & 0.00016 & 0.008096 & 0.004879 \\
\hline
\end{tabular}

$\mathrm{p}<0.05)$. These findings enabled the autumn abundance indices to be used for S-R studies.

The scattering of recruitment in relation to stock size, illustrated in Figure 4, shows a fairly clear link between the variables, though the relationship tends to weaken at higher stock levels.

As a result of the test to detect the best combination of monthly SST anomaly information to include in stock-recruitment relationships, the average value over the July-August period was selected. This is shown in Figure 5 for the period under study (19851998). It is worth noting that, during this period, the average SST were consistently lower in the western sector than in the east, but generally higher than the corresponding climatological values.

Table 1 lists the estimated equations for all the models, limited to those including the selected variable. Equation (6) emerges as the best fit to the data, accounting for about $80 \%$ of the total variance. Results suggest that introducing SST information enables us to justify up to $20 \%$ more of the variance than the $60 \%$ maximum obtained when the environmental factor is not considered. It is also worth noting that the estimation of the $\beta$ parameter of the Ricker model (Eq. 4) did not differ significantly from zero, whereas in the modified Ricker model (Eq. 6) all the parameters were highly significant $(\mathrm{p}<0.01$, Table 2$)$.

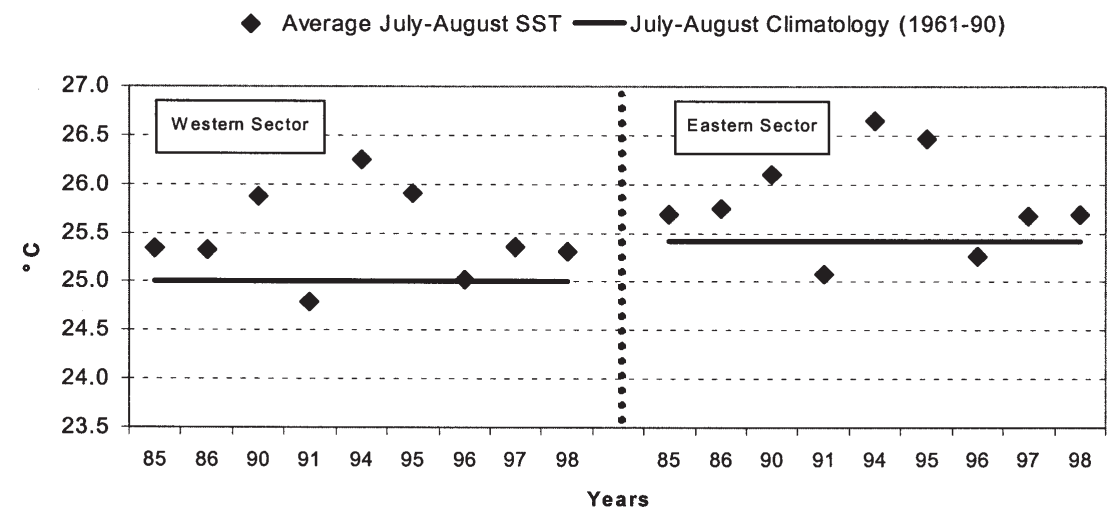

FIG. 5. - Average July-August SST time series and corresponding climatology (base period: 1961-90) relating to the two sites off the southern coast of Sicily shown in Fig. 1, approximately representative of the western and eastern sectors of the study area. The SST anomaly series for each sector were calculated as differences between the plotted variables. 


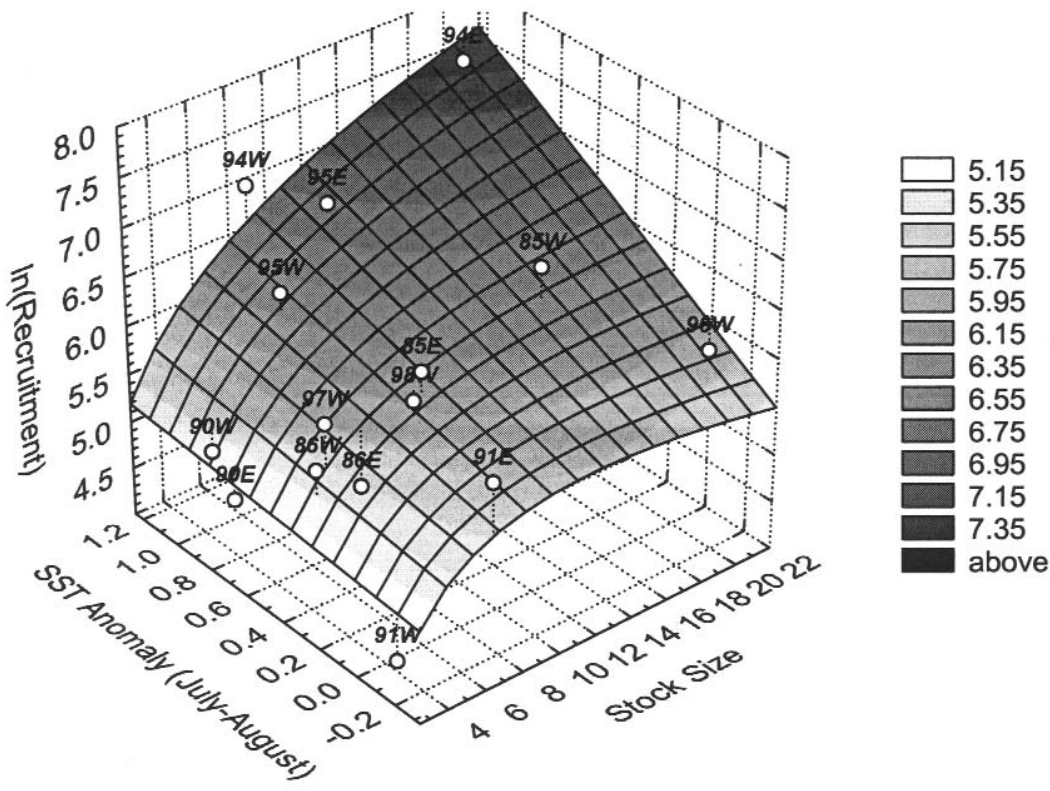

FIG. 6. - Recruitment (number of fish per $\left.\mathrm{km}^{2}\right)$ as a function of stock size $\left(\mathrm{kg}\right.$ per $\mathrm{km}^{2}$ ) and average July-August SST anomaly $\left({ }^{\circ} \mathrm{C}\right)$. SRR according to the Ricker model including SST anomalies as a masking effect (Eq. 6 in Table 1).

Figure 6 shows that the SST anomalies act as a moderating factor capable of depressing or boosting the recruitment corresponding to a given stock size level resulting from the application of a simple Ricker model alone. In particular, the estimated recruitment appears to be proportional to the SST anomaly, but the influence of the environmental factor grows with increasing stock size levels.

\section{DISCUSSION}

All the literature on environmental effects on recruitment, including the papers quoted in the introduction, refers to Atlantic stocks, mainly gadoids (Sanchez and Gil, 2000 and literature therein; Brander, 2000 and literature therein; papers in this volume), or to small pelagics.

Historically, maybe, the focus on both groups was mainly generated by the inability of "traditional" stock assessments to prevent severe collapses.

On the other hand, monitoring and possibly forecasting recruitment is of paramount importance in the Mediterranean, since a large proportion of catches consists of age groups 0 and 1 . This is the first time that environmental factors have been incorporated in stock-recruitment models to identify more realistic relationships for Mediterranean resources.
Results show that investigating SRR, taking the simultaneous effects of spawning stock and SST into account, may be crucial to short-term forecasting. Although the present configuration of the model (using autumn adult abundance) is inadequate for predicting the strength of recruitment, monitoring SST in July and August can be used to regulate fishing effort on the 0 group in the autumn in order to prevent recruitment over-fishing risks, taking the likely exploitation of the resources into account (Levi et al., 1993).

The first evidence of the dependence of red mullet recruitment on spawner abundance in the Mediterranean came from Fiorentino et al. (1998) and Zamboni et al. (2000) for the Ligurian Sea (north western Mediterranean). They modeled relationships with the classical Ricker and Beverton and Holt models without considering any effects of environmental parameters, showing a great variability in the scattering of recruitment around the regression model, possibly due to errors in measuring stock and recruitment and to variations in environmental factors.

As regards the red mullet of the Strait of Sicily, the Ricker model with SST anomalies affecting recruitment as a "masking factor" (for July-August) exhibited the best fit to data $\left(\mathrm{R}^{2}=0.80\right)$.

Results suggest that positive SST anomalies positively affect recruitment. 
Available data do not support the claim that SST modulates recruitment strength by affecting the development of early juvenile stages (direct or physiological control) or regulating their feeding and settlement (indirect or ecological control).

However, since spawning in the area occurs mainly in May-June at depths between 50 and $200 \mathrm{~m}$ (Fig. 3a) and recruitment occurs on bottoms very close to the coast in August-September $(10-30 \mathrm{~m}$, Fig. 3b), a decreased offshore transport can be postulated as a factor favoring the success of recruitment. Assuming that SST directly modulates the survival rates of pelagic eggs and larvae (Ellertsen $e t$ al., 1989; Pepin, 1991), SST anomalies in May-June might be expected to be more important in SRRs than in July-August. Given that recruitment dynamics were positively influenced by July-August high anomalies (warmer than average surface water), it seems more reasonable to consider a reduced upwelling regime and a consequent lower level of offshore transport (testified by high SST anomaly values) as the key factor capable of supporting the survival of juvenile stages during their migration towards the coastal nursery areas. Conversely, lower than average SST values could be a proxy of processes capable of enhancing pre-recruit mortality rates directly (offshore transport obstructing migration) and/or indirectly (poor food availability induced by turbulent mixing of sea surface layers).

Future research will concentrate along two main lines.

On the one hand, more data (e.g. satellite as in Demarcq, 2000) and longer time series are needed before drawing firmer conclusions and further reducing uncertainty. These results must be considered with caution because the good fit to 1985-1998 data, obtained by including environmental parameters in the SRR, has to be validated in future investigations. The relationships between SST, upwelling and offshore currents in the area also need to be better defined and/or maybe synthesized (Bakun, 1996).

On the other hand, while fishing seemed to suggest the existence of two separate spawning areas, one for the Adventure Bank and the other for the Malta shelf, such evidence was merely used here to strengthen a general model for red mullet on the shelf of southern Sicily. Whether two meta-populations inhabit the two aforesaid areas should also be clarified by further research.

It is also to be hoped that parallel work, e.g. on small pelagics and the environment (Mazzola et al.,
1998, 2000; Garcia Lafuente et al., 2001) in the same areas will improve forecasting by explaining factors involved in the causal chain (plankton biomass and seston concentrations, permanence of local gyrals and meanders) on the mesoscale.

\section{ACKNOWLEDGMENTS}

The authors wish to thank Manuel Varela for helpful comments and suggestions on the manuscript.

\section{REFERENCES}

Astraldi, M., G.P. Gasparini, S. Sparnocchia, M. Moretti and E. Sansone. - 1996. The characteristics of the water masses and water transport in the Sicily Strait at long time scales. In: F. Brian (ed.), Dynamics of Mediterranean Straits and Channels, CIESM Science Series, 2: 95-115.

Bailey, K.M. - 1981. Larval Transport and Recruitment of Pacific Hake Merluccius productus. Mar. Ecol. Prog. Se., 6: 1 - 9.

Bakun, A. - 1985. Comparative studies and the recruitment problem: searching for generalizations. CalCOFI Rep., 26: 30- 40.

Bakun, A. - 1996. Patterns in the ocean: ocean processes and marine population dynamics. California Sea Grant, La Jolla, California. $323 \mathrm{pp}$.

Bethoux, J.P. - 1980. Budgets of the Mediterranean Sea. Their dependence on the local climate and on the characteristics of the Atlantic Waters. Oceanol. Acta, 2(2): 157-163.

Boeuf, G. - 1988. Le facteur temperature et le physiologie des poissons. Piscic. Fr., 91: 15-29.

Botsford, L.W. - 1987. Analysis of environmental influences on population dynamics. In: Vincent, T.L., Y. Cohen, W.J. Grantham, G.P. Kirkwood and J.M. Skowronsky (Eds.), Modelling and Management of Resources under Uncertainty, pp. 54-65. Springer-Verlag. Berlin.

Brander, K. - 1997. Effects of climate change on Cod stocks. In: Wood, C.M. and D.G. McDonald (eds.), Global Warming: Implications for freshwater and marine fish. Society for Experimental Biology. Seminar Series, 61, pp. 255-278. Cambridge University Press.

Brander, K. - 2000. Effects of environmental variability on growth and recruitment in cod (Gadus morhua) using a comparative approach. Oceanologica Acta, 23: 485-496.

Brett, J.R. - 1970. Temperature - Fishes. In: O. Kinne (ed.), Marine ecology. Volume 1. Environmental factors. Part 1, pp. 514-616. Wiley Interscience, Glasglow.

Buckley, L.J. and R.G. Lough. - 1987. Recent growth, biochemical composition, and prey field of larval haddock (Melanogrammus aeglefinus) and Atlantic cod (Gadus morhua) on Georges Bank. Can. J. Fish. Aquat. Sci., 44: 14-25.

Caddy, J.F. - 1990. Options for the regulation of Mediterranean Demersal fisheries. Nat. Resour. Model., 4(4): 427-475.

Caddy, J.F. - 1998. GFCM and its future relationship to marine science. In: Gaps in Mediterranean Fishery Science. CIESM Workshop Series, 5: 7-10.

Corten, A. -1986 . On the causes of the recruitment failure of herring in the central and northern North Sea in the years 19721978. J. Cons. int. Explor. Mer., 42: 281-294.

Cushing, D.H. - 1982. Climate and Fisheries. Academic Press, London. 376 pp.

Chambers, R.H. and E. A. Trippel (eds.). - 1997. Early Life History and Recruitment in Fish Populations. Chapman \& Hall. Fish and Fisheries Series, 21. London. 596 pp.

Daskalov, G. -1999 . Relating fish recruitment to stock biomass and physical environment in the Black Sea using generalized additive models. Fish. Res., 41: 1-23.

Demarcq, H. and V. Faure. - 2000. Coastal upwelling and associated retention indices derived from satellite SST. Application to Octopus vulgaris recruitment. Oceanologica Acta, 23: 391-408. 
Ellertsen, B., P. Fossum, P. Solemdal and S. Sundby - 1989. Relation between temperature and survival of eggs and first feeding larvae of Northeast Arctic cod (Gadus morhua). ICES Rapp. Proc.-Verb., 191: 209-214.

Farrugio, H. and C. Papaconstantinou. - 1998. The status of fisheries resources of the Mediterranean. In: Gaps in Mediterranean Fishery Science. Ciesm Workshop Series, 5: 13-24.

Fiorentini, L., J.F. Caddy and J.I. de Leiva. - 1997. Long- and short-term trends of Mediterranean Fishery Resources.. Studies and Reviews. General Fisheries Council for the Mediterranean, 69. FAO, Rome. 72 pp.

Fiorentino, F., A. Zamboni, L. Orsi Relini and G. Relini. - 1998. Relazioni "adulti/reclute" in Mullus barbatus (L., 1758) (Osteichthyes - Mullidae) del Mar Ligure: uno studio preliminare. Biol. Mar. Mediterr., 5(1): 308-316.

Fry, F.E.J. - 1947. Effects of the environment on animal activity. Univ. Toronto Stud., Biol. Ser. 55: 1-62.

Garrod, D.J. and A. Shumacher. - 1994. North Atlantic cod: the broad canvas. ICES mar. Sci. Symp., 198: 59-76.

García Lafuente, J., A. García, S. Mazzola, L. Quintanilla, J. Delgado, A. Cuttitta and B. Patti. - 2001. Hydrographic phenomena influencing early life stages of the Sicilian Channel anchovy. In press in Fishery Oceanography.

Gayanilo, F.C.Jr., P. Sparre and D. Pauly. - 1996. The FAOICLARM Stock Assessment Tools (FiSAT) User's Guide. FAO Comput. Inf. Ser. (Fish.), N.8. Rome, FAO. 126 pp.

Glantz, M.H. - 1992. Climate Variability, Climate Change and Fisheries. Cambridge University Press, Cambridge. 450 pp.

Hilborn, R. and C.J. Walters. - 1992. Quantitative Fisheries Stock Assessment. Choice, Dynamics and Uncertainty. Chapman and Hall, London. 570 pp.

Iles, T.C. and R.J.H. Beverton. - 1998. Stock, recruitment and moderating processes in flatfish. J. Sea Res., 39: 41-55.

Kenneth, T. F. and J.E. Carscadden. - 1989. Factors affecting recruitment variability of Capelin (Mallotus villosus) in the Northwest Atlantic. J. Cons. int. Explor. Mer., 45: 146-164.

Lasker, R. - 1981. Factors contributing to variable recruitment of the northern anchovy (Engraulis mordax) in the California Current: contrasting years 1975 through 1978. ICES Rapp. Proc.Verb., 178: 375-388.

Laevastu, T. - 1993. Marine Climate, Weather and Fisheries. Fishing New Books, Oxford. 204 pp.

Levi, D. - 1991. Recruitment calendar and fishing ban: the case of the Sicilian Channel. Oebalia, 17(ns): 237-257.

Levi, D., M.G. Andreoli and P. Rizzo. - 1992. Growth curves from representative samples of fish populations as possible hints for the identification of unit stock. The case study of Red mullet from the Sicilian Channel. In: G. Colombo, I. Ferrari, V.U. Ceccherelli and R. Rossi (eds.), Proceedings of the 25th European Marine Biology Symposium, Ferrara, 1990, pp. 299-306. Olsen and Olsen, Printers and Publishers, Fredensborg.

Levi, D., M.G. Andreoli and G.B. Giusto. - 1993. An analysis based on trawl-survey data of the state of the "Italian" stock of Mullus barbatus in the Sicilian Channel, including management advice. Fish. Res., 17: 333-341.

Levi, D., M.G. Andreoli, E. Arneri, G. Giannetti and P. Rizzo. 1994. Otolith reading as a tool for stock identification. Fish. Res., 20: 97-107.

Levi, D., S. Ragonese, M.G. Andreoli, G. Norrito, P. Rizzo, G.B. Giusto, S. Gancitano, G. Sinacori, G. Bono, G. Garofalo and L. Cannizzaro. - 1998. Sintesi delle ricerche sulle risorse demersali dello Stretto di Sicilia (Mediterraneo Centrale) negli anni 1985-1997 svolte nell'ambito della legge 41/82. Biol. Mar. Mediterr., 5 (3): 130-139.

Lo Bianco, S. - 1908-1909. Notizie riguardanti specialmente il periodo di maturità sessuale degli animali del Golfo di Napoli. Mitt. Zool. Stn. Neapel, 19: 513-571.

Manzella, G.M.R., G.P. Gasparini, and M. Astraldi. - 1988. Water exchange between the eastern and western Mediterranean through the Strait of Sicily. Deep-Sea Res., 35(6): 1021-1035.

Mazzola, S., A. García and J. García Lafuente. - 1998. Distribution, biology and biomass estimates of the Sicilian Channel Anchovy. Interim Report. Commission of the European Communities. Directorate General for Fisheries (DG-XIV). 38 pp. (mimeo).

Mazzola, S., A. García and J. García Lafuente. - 2000. Distribution, biology and biomass estimates of the Sicilian Channel Anchovy.
Final Report. Commission of the European Communities. Directorate General for Fisheries (DG-XIV). 152 pp. (mimeo).

Montalenti, G. - 1933. Mullidae: In: Uova, larve e stadi giovanili di Teleostei. Fauna e Flora del Golfo di Napoli, 38.

Neill, W.H., J.M. Miller, H.W. Van der Veer and K.D. Winemuller. - 1994. Ecophysiology of marine fish recruitment: a conceptual framework for understanding interannual variability. Neth. J. Sea Res., 32: 135-152.

Nelson, W.M., M. Ingham and W. Schaaf. - 1977. Larval transport and year-class strength of Atlantic menhaden (Brevoortia tyrannus). Fish. Bull., 75: 23-41.

Onken, R., and J. Sellschopp. - 1998. Seasonal Variability of Flow Instabilities in the Strait of Sicily. J. Geophys. Res. (C Oceans), 103, C11, 24799-24820.

Parrish, R.H., C.S. Nelson and A. Bakun. - 1981. Transport Mechanisms and Reproductive Success of Fishes in the California Current. Biological Oceanography, 1(2): 175-203.

Peterman, R.M. and M.J. Bradford. - 1987. Wind speed and mortality rate of a marine fish, the northern anchovy (Engraulis mordax). Science, 235: 354-356.

Piccioni, A., M. Gabriele, E. Salusti and E. Zambianchi. - 1988. Wind-induced upwellings off the southern coast of Sicily. Oceanol. Acta, 11(4): 309-314.

Pihl, L. - 1990. Year-class strength regulation in plaice (Pleuronectes platessa L.) on the Swedish west coast. Hydrobiologia, 195: 79-88.

Relini, G. - 1998. Demersal trawl surveys in Italian Seas. Presented at the International Symposium "Assessment of demersal resources by direct methods in the Mediterranean and adjacent seas", Pisa 18-21 March 1998. 20 pp. (mimeo).

Reynolds, R.W. and T.M. Smith. - 1994. Improved global sea surface temperature analyses. J. Clim., 7: 929-948.

Robinson, A.R., M.Golnaraghi, W.G. Leslie, A. Artegiani, A. Hecht, E. Lazzoni, A. Michelato, E. Sansone, A. Theocharis and U. Unluata. - 1991. The Eastern Mediterranean General Circulation: Features, Structure and Variability. Dynamics of Atmospheres and Oceans, 15(3-5): 215-240.

Sanchez, F. and J.Gil - 2000. Hydrographic mesoscale structures and Poleward Current as determinant of hake (Merluccius merluccius) recruitment in southern Bay of Biscay. ICES J. Mar. Sci., 57: 152-170.

Saville, A. and Bailey R.S. - 1980. The assessment and management of the herring stocks in the North Sea and to the West of Scotland. Rapp. P. V. Reun. Cons. Int. Explor. Mer. 177 : 112-142.

Sissenwine, M.P. - 1984. Why do fish populations vary? In: R. M. May (Editor); Exploitation of marine communities. Dahlem Konferenzen, Springer Verlag, Berlin: 59-94.

Sissenwine, M.P. and J.G. Shepherd. - 1987. An alternative perspective on recruitment overfishing and biological reference points. Can. J. Fish. Aquat. Sci., 44: 913-918.

Smith, T.M. and R.W. Reynolds. - 1998. A high-resolution global sea surface temperature climatology for the 1961-90 base period. J. Clim., 11: 3320-3323.

Southward, A. J. and Boalch, G. T. - 1994. The effect of changing climate on marine life: past events and future predictions. In: S. Fisher (Ed.), Man and the maritime environment, Exeter Maritime Studies, 9: 101-143.

Templeman, W. and Fleming, A.M. - 1953. Long term changes in the abundance of marine animals. Int. Comm. Northw. Atl. Fish. Ann. Proc., 3: 78-86.

Van der Veer, H.W., P. Ruardij, A. Van der Berg and H. Ridderinkhof. - 1998. Impact of the interannual variability in hydrodynamic circulation on eggs and larval transport of Plaice Pleuronectes platessa L. in the southern North Sea. J. Sea Res. 39: 29-40.

Walters, C.J. and J.S. Collie. - 1988. Is research on environmental factors useful to fisheries management? Can. J. Fish. Aquat. Sci., 45: 1848-1854.

Wood, C.M. and D.G. McDonald (eds.) - 1997. Global Warming: Implications for freshwater and marine fish. Society for Experimental Biology. Seminar Series, 61. Cambridge University Press: 425 p.

Zamboni, A., M. Rossi, A. Mannini, A. Gatto and F. Fiorentino. 2000. La capacità di rinnovo della triglia di fango (Mullus barbatus, L., 1758) in Mar Ligure sulla base della relazione adultireclute. Biol. Mar. Mediterr., 7 (1): in press. 